Vol. 18 (2009): 35-44.

\title{
Effect of dietary linseed supplements on $\omega-3$ PUFA content and on IGF-I expression in broiler tissues
}

\author{
Zinaida Saprõkina ${ }^{1 *}$, Avo Karus ${ }^{1}$, Sirje Kuusik ${ }^{4}$, Harald Tikk² ${ }^{2}$ Peeter Järv ${ }^{3}$, Riina Soidla ${ }^{3}$, Aleksander \\ Lember $^{2}$, Helgi Kaldmäe ${ }^{4}$, Virge Karus ${ }^{1}$ and Mati Roasto ${ }^{3}$ \\ ${ }^{1}$ Chemistry, Institute of Veterinary Medicine and Animal Science, Estonian University of Life Sciences, \\ Kreutzwaldi 1A, 51010 Tartu, Estonia \\ ${ }^{2}$ Department of Small Farm Animal and Poultry Husbandry, Institute of Veterinary Medicine and Animal Sciences, \\ Estonian University of Life Sciences, Tartu, Estonia \\ ${ }^{3}$ Department of Food Sciences, Institute of Veterinary Medicine and Animal Sciences, \\ Estonian University of Life Sciences, Tartu, Estonia \\ ${ }^{4}$ Department of Nutrition, Institute of Veterinary Medicine and Animal Sciences, \\ Estonian University of Life Sciences, Tartu, Estonia \\ *e-mail: zinaida.saprokina@emu.ee
}

\begin{abstract}
The aim of this study was to evaluate the effect of $\omega$-3 PUFA-rich linseed-supplemented diet on the $\omega-6 / \omega-3$ PUFA content and IGF-I mRNA expression in broiler tissues. Broilers (50 of $21 \mathrm{~d}$ old and 90 of $42 \mathrm{~d}$ old) were divided into groups according to dietary additives: $1.5 \%$ linseed oil (LO), $3.0 \%$ LO, $15 \%$ linseed cake (LC) and 30\% LC and to the duration of modified feeding (1-21, 1-42 and 22-42 days). PUFA content in breast muscles was assayed by gas chromatography and IGF-I mRNA content in liver, muscle and leukocytes was measured by one step RT-PCR. The experimental diets improved the $\omega-6 / \omega-3$ PUFA ratio through a threefold increase in the $\omega-3$ PUFA content in the breast muscle. The changes in PUFA content were accompanied by changes in IGF-1 gene expression levels in tissues. Therefore, both paracrine and autocrine manner of IGF-1 action are likely to be involved. $15 \% \mathrm{LC}$ at starting period or $1.5 \% \mathrm{LO}$ in final diet can be advised as optimal for enriching broiler meat with $\omega-3$ fatty acids.
\end{abstract}

Key-words: broiler, nutrition, linseed, PUFA, IGF-1 expression

(C) Agricultural and Food Science

Manuscript received December 2006 
Saprõkina, Z. et al. Dietary linseed supplement effect on broiler IGF-1 expression

\section{Introduction}

In the last several years, cardiovascular diseases have become more frequent in Estonia and the rest of world. At the same time, the consumption of polyunsaturated $\omega-3$ fatty acid ( $\omega-3$ fatty acids or $\omega-3$ PUFA) has been shown to reduce the risk of arteriosclerosis. Unfortunately, as the human organism is unable to produce PUFAs; it is necessary to pick them up from food. The richest source of $\omega-3$ fatty acids is the fat of cold-water fish as well as flax, hemp, rape and linseed (Lopez-Ferrer et al. 2001). However most of the people do not like to use these products directly for food. Moreover oil capsules rich in $\omega-3$ fatty acids, produced by many companies are relatively expensive. The alternative is to consume animal and bird products whose organs are enriched with $\omega$-3 PUFA.

The effect of transmitted fatty acids from dietary vegetable sources on poultry tissues is known (Lopez-Ferrer et al. 2001, Hämmal 2004, Mazzuco et al. 2005, and Lember et al. 2006). In our previous study, $\omega$-3 fatty acid levels in breast muscle of quails were responding well to changes in dietary meal composition (Karus et al. 2007). It therefore can be presumed that the enrichment of broiler meat with $\omega-3$ fatty acid can be achieved by feeding the birds with linseed (Linum usitatissinum) meal. However, the optimal content and duration of the supplementation that ascertain proper development and growth of broilers are not known at present.

We have sought to answer these questions by measuring the mRNA level of IGF-1 (insulin like growth factor-1). It has been suggested that higher $\omega$-3 PUFA diets could affect IGF-1 expression because IGF-1 mRNA level in liver and muscle was depended on the nutrition status (Heck et al. 2003, Guernec et al. 2004). Therefore, IGF-1 mRNA content in those tissues could give valuable information for establishing optimal linseed diets for enriching broiler muscles tissues with $\omega-3$ fatty acids.

In addition, we also studied the mechanism of IGF-1 action: endocrine, paracrine or autocrine, as this too can be important for increasing the $\omega-3$ fatty acid content and in improving $\omega-6 / \omega-3$ PUFA ratio in tissues using linseed meal (McMurtry et al. 1997, Beccavin et al. 2001, Heck et al. 2003, Giachetto et al. 2004).

\section{Material and Methods}

Experiments were carried out according to Estonian Animal Protection Act (13.12.2000/RT I 2004). The trial was conducted at A/S Tallegg in 2005. Test groups were located on private farms. In total 140 Ross 208 broilers were studied. As recommended (Tikk and Lember 2004), broilers were divided into 14 groups ( 5 males and 5 females in each) according to following dietary additives: 1.5 and $3.0 \%$ linseed oil, 15 and $30 \%$ linseed cake groups, feeding periods (1-21, 1-42 and 22-42 days) with additive nutrition plus two control groups (broilers at the age of 21 $\mathrm{d}$ and $42 \mathrm{~d}$ old). The dietary additives were given with granulated mixed concentrated feed as the basal feed containing $21.2 \%$ crude protein and $13.2 \mathrm{MJ} / \mathrm{kg}$ metabolizable energy. The content of crude fat and $\omega-3$ PUFA in diet are presented in Table 1.

Table 1. Content of crude fat and $\omega-3$ PUFA in diet.

\begin{tabular}{lcccc}
\hline & $\begin{array}{c}\text { Crude fat } \\
\text { content }\end{array}$ & $\begin{array}{c}\omega-3 \text { PUFA in } \\
\text { crude fat }\end{array}$ & $\begin{array}{c}\omega-3 \text { PUFA content in } \\
1 \mathrm{~g} \text { of feed }\end{array}$ & $\begin{array}{c}\omega-3 \text { PUFA content in } \\
\text { daily (30 g) diet }\end{array}$ \\
\hline Feeds & $\%$ & $\%$ & $\mathrm{mg}$ & $\mathrm{mg}$ \\
Linseed cake & 13.46 & 48.50 & 65 & - \\
Linseed oil & 96.00 & 52.97 & 509 & 5 \\
Mixed feed & 4.73 & 10.77 & 50 \\
\hline
\end{tabular}


Vol. 18 (2009): 35-44.

Tissue samples were taken immediately after slaughter (blood samples were taken from living birds before slaughtering), instantly frozen in dry ice and stored (about two hours) at $-20^{\circ} \mathrm{C}$ until use. Breast muscles were separated from the carcass, weighed and samples were taken for fatty acid analysis. Fatty acids were determined by gas chromatography in the form of methyl esters on 30 m Carbowax column (for more details see Karus 2007). The total content of saturated fatty acids, monounsaturated fatty acids, $\omega-3$ polyunsaturated fatty acids (PUFA) and $\omega-6$ PUFAs were calculated (Hämmal 2004, Tikk and Lember 2004, Lember et al. 2006, Karus et al. 2007).

Blood was collected from V. jugularis into disposable non-heparinised test tubes for IGF-1 analysis and into EDTA-diNa tubes for mRNA studies. Leukocyte mRNA was isolated using $m R N A$ isolation kit for bone/blood marrow (Roche Applied Science). Muscle and liver samples were disrupted and homogenized tissue using mortar and pestle. mRNA was isolated from 74-76 mg of homogenized using $m R N A$ isolation kit (Roche Applied Science).

Analysis of mRNA was performed with hot start one-step RT-PCR using LightCycler RNA Master SYBR Green I kit (Roche Applied Science) and LightCycler 1.2 Instrument. The PCR protocol was optimised on the basis of previous work (Pfaffl et al. 2002, Heck et al. 2003, Giachetto et al. 2004, Smolkina and Karus 2004) and the Roche LightCycler RNA master SYBR Green I method manual.

The complimentary DNA sequences were the same as reported by Pfaffl $(2001,2002)$ and were pretested in birds (Karus et al. 2007). The primers were synthesised by TIB MOLBIOL (www.tib-molbiol.com). Primer information and the TIB reference numbers are listed in Table 2.

GAPDH housekeeping gene was used for IGF-1 mRNA quantification (Smolkina and Karus 2004). Crossing points for IGF-1 expression analysis were estimated using the Fit Points option (LightCycler software version 3.5).

\section{Statistical Analyses}

Variation of polyunsaturated fatty acid content in parallel measurements of feeds has been negligibly small (Hämmal 2004). Therefore, the pooled samples were used for analyses and the values in Table 3 are presented as averages without standard deviation. Statistical analysis was performed using SYSTAT 10.0 software (SPSS) and R package (version 2.4.0.). The data of IGF-1 mRNA are represented as mean \pm SD. The homogeneity of variance for IGF-1 mRNA data was tested by the one-way ANOVA. When variances were comparable, the differences in IGF-1 gene expression regarding the changes in consuming duration or in additive yield were estimated by T-test with unequal variances.

One-way ANOVA dispersion analysis followed by Tukey posthoc test was performed to determine the effects of linseed meal on relationship between IGF-1 mRNA levels and $\omega-6 / \omega-3$ PUFA ratio. Furthermore Pearson's correlation coefficients between averages of IGF-1 mRNA and $\omega-6 / \omega-3$ PUFA ratio were calculated. Differences of $p<0.05$ were regarded as significant.

Table 2. The sequences, position and G/C content of the RT PCR primers

\begin{tabular}{lll}
\hline Primer & Sequence $\left(5^{\prime} \rightarrow 3^{\prime}\right)$ & GC $(\%)$ \\
\hline GAPDH f & CATTGACCTTCACTACATGGT & 42.9 \\
GAPDH r & ACCCTTCAAGTGAGCCCCAG & 60.0 \\
IGF-1 f & TCGCATCTCTTCTATCTGGCCCTGT & 52.0 \\
IGF-1 r & GCAGTACATCTCCAGCCTCCTCAGA & 56.0 \\
\hline $\mathrm{f}=$ forward; $r=$ reverse & &
\end{tabular}




\section{Results}

\section{Effect of dietary linseed additives on PUFA content in broiler breast muscle}

The broiler breast muscle fatty acid content data are presented in Table 3. We established that in comparison with control group, the linseed diet led to higher content of $\omega$-3 PUFA and lower $\omega-6 / \omega-3$ PUFA ratio in broiler breast muscle.

In comparison with control group, the experimental diets on average increased $\omega-3$ PUFA content by 3.3-fold and decreased the ratio of $\omega-6 / \omega-3$ PUFA approximately 3.5 -fold.

$\omega-6 / \omega-3$ PUFA ratio revealed a falling trend during the first 3 weeks of feeding trial (1-21 day), but this could be extended by completing the diet. The highest values of $\omega-3$ PUFA content and the lowest ratios of $\omega-6 / \omega-3$ PUFA in breast muscles were observed with diet containing $30 \%$ linseed cake during the last two weeks of study. In the case of longer feeding periods (1-42 day) the trend was similar - linseed cake additives improved $\omega-6 / \omega-3$ PUFA ratio in breast muscle even further.

\section{Effect of linseed rich diet on IGF-I ex- pression level in different broilers tissues}

In order to investigate the effects of linseed meal in broiler, we measured broiler leukocytes, liver and breast muscle IGF-1 mRNA level at different points in nutrition time (Table 4).

Despite relatively high variation, the IGF-1 expression level differs quantitatively between tissues. The relative content of IGF-1 mRNA in leukocytes tends to decrease in broilers fed with $30 \%$ linseed cake in first three weeks $(p<0.05)$ (different upper-case letters in Table 4).

After starting the diet (1-21 d), a slight increase in muscle IGF-1 mRNA level was observed.

However, the IGF-1 expression level differed significantly from that of the control group $(p<0.05)$ in the $15 \%$ linseed cake treatment group only.

IGF-1 expression in liver during the first 21day diet period was not affected by linseed meal. However, there was evidence suggesting decrease in the hepatic IGF-1 expression within higher linseed cake group $(p<0.05)$. Compared with the control group, the differences in IGF-1 expression in white blood cells after longer nutrition period

Table 3. Fatty acid composition ( $\%$ of total) in broiler breast muscle at different experimental diets.

\begin{tabular}{|c|c|c|c|c|c|c|c|c|c|c|c|c|c|c|}
\hline \multirow{2}{*}{$\begin{array}{l}\text { Fatty } \\
\text { acids }\end{array}$} & \multicolumn{2}{|c|}{$\begin{array}{l}\text { Control } \\
\text { group }\end{array}$} & \multicolumn{3}{|c|}{$1.5 \%$ linseed oil } & \multicolumn{3}{|c|}{$3.0 \%$ linseed oil } & \multicolumn{3}{|c|}{$15 \%$ linseed cake } & \multicolumn{3}{|c|}{$30 \%$ linseed cake } \\
\hline & $1-21$ & $1-42$ & $1-21$ & $1-42$ & $22-42$ & $1-21$ & $1-42$ & $22-42$ & $1-21$ & $1-42$ & $22-42$ & $1-21$ & $1-42$ & $22-42$ \\
\hline SAT & 36.0 & 36.3 & 34.3 & 33.7 & 33.1 & 32.7 & 30.7 & 31.3 & 35.3 & 31.4 & 31.8 & 32.2 & 30.8 & 29.8 \\
\hline MUFA & 25.3 & 32.6 & 27.1 & 29.2 & 31.1 & 19.2 & 30.6 & 28.1 & 19 & 22.6 & 25.0 & 19.6 & 23.7 & 18.7 \\
\hline $\begin{array}{l}\omega-6 \\
\text { PUFA }\end{array}$ & 29.1 & 22.6 & 23.7 & 21.8 & 21.2 & 26.3 & 20.5 & 21.3 & 26.1 & 23.2 & 22.1 & 26.0 & 22.6 & 23.6 \\
\hline $\begin{array}{l}\omega-3 \\
\text { PUFA }\end{array}$ & 5.5 & 5.2 & 12.1 & 13.1 & 12.3 & 19.2 & 16.0 & 17.1 & 16.4 & 20.1 & 18.3 & 19.7 & 21.1 & 25.5 \\
\hline $\begin{array}{l}\omega-6 / \omega-3 \\
\text { PUFA }\end{array}$ & 5.30 & 4.35 & 1.96 & 1.66 & 1.72 & 1.37 & 1.28 & 1.25 & 1.60 & 1.15 & 1.21 & 1.32 & 1.07 & 0.93 \\
\hline
\end{tabular}

Mean values $(\mathrm{n}=10)$ are percent of total fatty acids: SAT, sum of 14:0, 15:0, 16:0, 17:0, 18:0 and 20:0. MUFA, sum of 16:1, 17:1, 18:1 and 20:1. $\omega-3$ PUFA, sum of 18:3n3, 20:5n3, 22:5n3 and 22:6n3. $\omega-6$ PUFA sum of 18:2n6 and 20:4n6. 
Vol. 18 (2009): 35-44.

Table 4. IGF-1 mRNA relative content in broiler leukocytes, liver and breast muscle

\begin{tabular}{|c|c|c|c|c|}
\hline Bird group & Period of nutrition & IGF-1 in blood & IGF-1 in liver & IGF-1 in muscle \\
\hline \multirow[t]{2}{*}{ Control } & $1-21$ & $0.5 \pm 0.3^{\mathrm{A}}$ & $14 \pm 25$ & $0.7 \pm 0.5^{\mathrm{A}}$ \\
\hline & $1-42$ & $0.1 \pm 0.1^{\mathrm{A}}$ & $1.3 \pm 1.3^{\mathrm{A}}$ & $0.1 \pm 0.2^{\mathrm{A}}$ \\
\hline \multirow[t]{3}{*}{$1.5 \%$ linseed oil group } & $1-21$ & $1.3 \pm 1.2^{\mathrm{A}}$ & $0.3 \pm 0.7$ & $1.9 \pm 2.2$ \\
\hline & $1-42$ & $0.2 \pm 0.2^{b}$ & $0.2 \pm 0.2^{\mathrm{B}}$ & $0.4 \pm 0.4^{\mathrm{Ab}}$ \\
\hline & $22-42$ & $0.7 \pm 0.6^{\mathrm{Ba}}$ & $2.7 \pm 2.2 \mathrm{Ba}$ & $0.7 \pm 1.2$ \\
\hline \multirow[t]{3}{*}{$3.0 \%$ linseed oil group } & $1-21$ & $1.0 \pm 0.6^{\mathrm{Aa}}$ & $0.6 \pm 0.6$ & $4.3 \pm 7.6$ \\
\hline & $1-42$ & $0.2 \pm 0.1^{b}$ & $1.0 \pm 2.0$ & $1.5 \pm 0.9 \mathrm{Ba}$ \\
\hline & $22-42$ & $0.1 \pm 0.1^{\mathrm{Ab}}$ & $1.5 \pm 1.4$ & $0.1 \pm 0.1^{\mathrm{Ab}}$ \\
\hline \multirow[t]{3}{*}{$15 \%$ linseed cake group } & $1-21$ & $2.4 \pm 2.0^{\mathrm{Aa}}$ & $0.6 \pm 0.4^{\mathrm{A}}$ & $7.0 \pm 9.3^{\text {в }}$ \\
\hline & $1-42$ & $0.8 \pm 1.4^{b}$ & $0.4 \pm 0.5$ & $0.1 \pm 0.1^{\mathrm{A}}$ \\
\hline & $22-42$ & $0.3 \pm 0.2^{\mathrm{Bb}}$ & $3.0 \pm 3.7$ & $0.6 \pm 0.7^{\mathrm{A}}$ \\
\hline \multirow[t]{3}{*}{$30 \%$ linseed cake group } & $1-21$ & $0.2 \pm 0.0^{\mathrm{Ba}}$ & $0.3 \pm 0.2^{\text {в }}$ & $1.0 \pm 1.0^{\mathrm{b}}$ \\
\hline & $1-42$ & $0.3 \pm 0.1^{\mathrm{Bb}}$ & $4.0 \pm 5.5$ & $0.1 \pm 0.1^{\mathrm{Aa}}$ \\
\hline & $22-42$ & $0.3 \pm 0.2^{\mathrm{Bb}}$ & $5.6 \pm 7.8$ & $0.6 \pm 1.3^{\mathrm{A}}$ \\
\hline
\end{tabular}

The IGF-1 mRNA was measured by real time RT-PCR and normalized by GAPDH mRNA levels. Ratios (arbitrary unit) are means \pm SD, by using a test of homogeneity of variances. The number of birds in groups ranged from $n=5-10$.

Different upper-case letters designate significant differences $(p<0.05)$ between different bird groups at the same nutrition periods.

Different lower-case letters designate significant differences $(p<0.05)$ between nutrition period at the same bird group.

(1-42 days) were observed in $30 \%$ linseed cake group $(p<0.05)$. In muscle, the highest level of IGF-1 transcription was observed in 3.0\% linseed oil group $(p<0.05)$.

Finalizing feeding with $3.0 \%$ linseed oil at 22-42 days decreased the IGF-1 mRNA content in leukocytes compared with other supplements. Nevertheless, small effect on IGF-1 anabolism was found in relation to others diets $(p<0.05)$. In muscle, the most significant effect was observed in $1.5 \%$ linseed oil group $(p<0.05)$. Double increase of IGF-1 mRNA in liver during the same period was not statistically significant.

The effect of linseed additives on IGF-1 depends on the formulation and dosing (different lower case letters in Table 4). Continuous effects on IGF-1 expression were observed with $1.5 \%$ linseed oil diets in blood and muscle: IGF-1 mRNA was higher in 22-42 day nutrition period compared with $1-42$ day period $(p<0.05)$. In case of other diets, the initial 21-day feeding had stronger effect than $1-42$ or $22-42$ day periods for IGF-1 mRNA relative content in leukocytes.

The difference in the IGF-1 mRNA content in leukocytes among female and male broilers at age of 3 weeks was detected only in the control group $(p<0.05)$. In other groups no significant genderbased differences were found $(p>0.1)$.

\section{The effect of linseed rich diet on the relationship between IGF-I expression and $\omega-6 / \omega-3$ PUFA ratio}

We calculated the correlation coefficients between IGF-1 expression level and $\omega-6 / \omega-3$ PUFA ratio in broilers (Table 5). 
Saprõkina, Z. et al. Dietary linseed supplement effect on broiler IGF-1 expression

Table 5. The correlation between IGF-1 mRNA relative content and $\omega-6 / \omega-3$ PUFA ratio in different feeding groups ${ }^{1}$.

\begin{tabular}{lccc}
\hline Additive & IGF-1 in Blood & IGF-1 in Liver & IGF-1 in Muscle \\
\hline $1.5 \%$ LO & 0.95 & -0.09 & 0.37 \\
$3.0 \%$ LO & 0.98 & -0.93 & $0.99(7)^{* *}$ \\
$15 \%$ LC & 0.94 & -0.32 & $0.99(7)^{* *}$ \\
$30 \%$ LC & $-0.99 *$ & $-0.99(8)^{* *}$ & 0.55 \\
\hline
\end{tabular}

$* p<0.1 ; * * p<0.05$; (Pearson correlation coefficient, $p$ value - two tailed)

${ }^{1}$ the means from different feeding groups for $\omega-6 / \omega-3$ PUFA ratio and IGF-1 mRNA was compared

LO $=$ Linseed oil, $\mathrm{LC}=$ Linseed cake

IGF-1 mRNA relative content
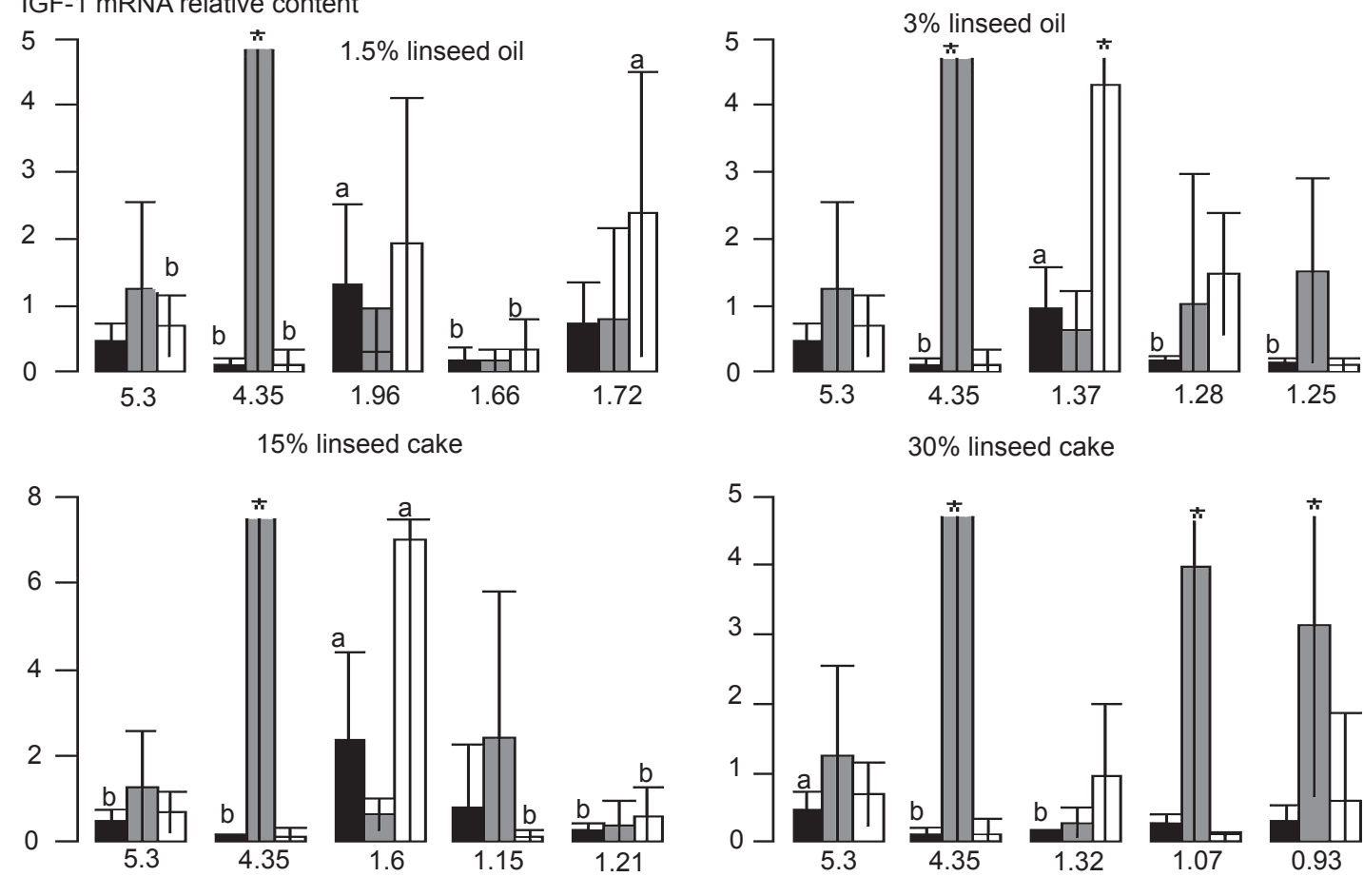

blood

$\square$ liver

$\square$ muscle

Fig. 1. The effect of different experimental diets on the relationship between absorbed $\omega-6 / \omega-3$ PUFA ratio in broiler tissues and IGF-1 mRNA relative content observed from blood, muscle and liver tissues. On x-axis there afe five feeding groups: control 1-21 d, control 1-42 d, supplemented 1-21 d, supplemented 1-42 d, supplemented 22-42 d. The levels of IGF-1 mRNA were normalized using GAPDH level. Each bar represents the mean $\pm \mathrm{SEM}$.

ab Different letters denote difference $(p<0.05)$ in means among diets

* Each bar that has SEM scaled out, does not represent statistical importance

The effects of linseed supplements were studied additionally by ANOVA dispersion analysis (Fig. 1).
Significant relationship between muscle IGF-1 mRNA relative content and $\omega-6 / \omega-3$ PUFA ratio was demonstrated in the case of $1.5 \%$ linseed oil 
Vol. 18 (2009): 35-44.

and $15 \%$ linseed cake diets $(p<0.05)$. It was confirmed by Pearson correlation coefficient values.

IGF-1 mRNA level in leukocytes affected the $\omega-6 / \omega-3$ PUFA ratio most in case of $1.5 \%$ linseed oil diet during the first three weeks of 42-day experiment period $(p<0.05)$. Doubled dietary oil groups showed (comprehensive) additive effect. There was also positive correlation between leukocyte IGF-1 mRNA and $\omega-6 / \omega-3$ PUFA ratio in different linseed oil supplemented diets.

Negative correlation, observed between IGF1 gene expression in leukocytes and $\omega-6 / \omega-3$ PUFA ratio in case of $30 \%$ linseed cake rich diet $(p<0.1)$ was in agreement with findings from ANOVA - control group values were affected by $\operatorname{diet}(p<0.05)$.

No correlation was detected between IGF-1 expression in liver and $\omega-6 / \omega-3$ PUFA ratio.

\section{Discussion}

We have demonstrated that linseed-supplements (Linum usitatissinum) can enhance the nutritional quality of broiler meat through better $\omega-6 / \omega-3$ PUFA ratio which results from threefold $\omega-3$ PUFA content increase in breast muscle. The possibility of fatty acids transfer from linseed meal to broiler tissue is in agreement with previous studies (Lopez-Ferrer et al. 2001, Hämmal 2004, Lember et al. 2006, Tikk and Lember 2004, Karus et al. 2007).

Our findings, that shorter feeding periods (in our case 22-42 day) are preferable for diets with higher concentration of $\omega-3$ PUFA, are supported by literature (Tikk and Lember 2004, Waldroup and Waldroup 2005, Lember et al. 2006). In addition, we established that smaller amounts of linseed oil or cake additives gave better results in the case of 42-day diet.

In the present study the calculated $\omega-6 / \omega-3$ PUFA ratio in broiler breast muscles from different experimental diets was around the $1: 1$, which may be attributed to the optimal metabolism of fats and proportional production of different prostaglandin's (Watkins et al. 1997). In order to understand better the possibility of fatty acids being absorbed from linseed meal to broiler tissues, and to explain whether linseed product is preferable for broiler breast muscle enrichment with $\omega$-3 PUFA, we also studied IGF-1 expression. An attempt had also been previously made to replace linseed oil with cheaper feeds of local origin - e.g. linseed cake (Lember et al. 2006), as oil is expensive and feeding with it would increase the cost of broiler meat.

Linseed meal can affect the morphology of poultry body and carcass characterization (LopezFerrer et al. 2001, Lember et al. 2006) and IGF-1 (McMurtry et al. 1997, Beccavin et al. 2001, Giachetto et al. 2004, Guernec et al. 2004). Although the effect of high $\omega$-3 PUFA diets on the IGF-1 mRNA levels observed in the current study is difficult to interpret, we have shown that neither IGF-1 gene expression nor PUFA content are associated with sex. This result is similar to the findings of Yun et al. (2005) and Lember et al. (2006) and suggests that PUFA utilization could be related to IGF1. Moreover, we found that despite relatively high variation in IGF-1 mRNA in different tissues, IGF1 mRNA relative content depends on the source of linseed oil as well as the feeding regimen.

The fraction of PUFA absorbed from the feed into breast muscles was similar in broilers fed with either 3\% linseed oil or 30\% linseed cake during the first 3-week period. Whereas IGF-1 expression in liver and in muscle showed tendency to depend on the diet, significant difference observed in leukocytes at $30 \%$ linseed cake diet showing lower mRNA content. It should be also mentioned that in total, IGF-1 mRNA content in leukocytes correlated negatively with $\omega-6 / \omega-3$ PUFA ratio in broilers fed with the elevated linseed cake content. Based on the finding that $30 \%$ linseed cake diet during first three weeks of posthatch growth does not lead to subsequent enrichment of broiler meat with $\omega-3$ PUFA and on the results by McMurtry et al. (1997) it appears that better availability of PUFA does not result in elevated IGF-1 expression.

Previous research has also pointed out that the production and action of IGF-1 are selectively influenced by the dietary supply of proteins (McMurtry et al. 1997, Katsumata et al. 2002), whose deficiency was associated with low circulating con- 


\section{Saprõkina, Z. et al. Dietary linseed supplement effect on broiler IGF-1 expression}

centration of IGF-1 in blood and reduced production in liver (cited in Katsumata et al. 2002). In addition, plasma IGF-1 concentration and hepatic IGF-1 mRNA gene expression in young chickens are lowered by feed restriction and vice verse (cited in Mazucco et al. 2005). The consequences on muscle IGFs mRNA levels remain undetermined in chickens (cited in Guernec et al. 2004). In the current study, the IGF-1 mRNA level in breast muscle samples of broilers was measured as being significantly higher after initial three weeks consumption of $15 \%$ linseed cake, when compared with the control group.

The precise role of IGF-1 in the monitoring of nutritional changes is still a matter of debate, but we propose that with low linseed cake consumption in the starting diet, the endocrine manner of IGF-1 action was diminished or changed very little. Moreover, the significant effect of $15 \%$ linseed cake diet on the relationship between muscle IGF-1 mRNA level and $\omega-6 / \omega-3$ PUFA ratio was confirmed by positive correlation. This reflects that paracrine and/or autocrine mechanism of IGF-1 are of higher importance. Our hypothesis is supported by recent data: larger amounts of linseed cake can depress growth of poultry (Ciceran 2004), which is usually associated with IGF-1 in endocrine manner (Yun et al. 2005). Withal (cited in Guernec et al. 2004) has also noted that paracrine IGF-I may be more important for de novo fatty synthesis and muscle growth than endocrine or circulating IGF-I. As discussed above, the trend towards IGF-1 gene expression increase in chicken breast muscle can be seen not only in three weeks (Yun et al. 2005) but even 4 weeks and it remained high at 6 weeks of chicken age (Guernec et al. 2004). In the current study, the elevation in IGF-1 mRNA in broiler breast muscle was observed at the age of 42 days after $1.5 \%$ linseed oil of final diet (22-42 day). The influence of low linseed oil diet on relationship between muscle IGF-1 gene expression and $\omega-6 / \omega-3$ PUFA ratio was even more significant. Our findings suggest that IGF-1 action in paracrine manner may be situated with $\omega-6 / \omega-3$ PUFA ratio improvement and with $\omega-3$ PUFA increasing. The report by Dunn et al. (2003) suggests that a negative effect of flaxseed on IGF-1 mRNA content in the longissimus dorsi muscle of cattle may be caused by differences in IGF-1 gene expression, species differences or even differences between tissues.

The postulate that IGF-1 can act in paracrine and autocrine manner in PUFA absorption from $\omega-3$ PUFA rich feed is also confirmed by insignificant changes in liver IGF-1 mRNA of all broiler groups. The only significant differences in hepatic IGF-1 mRNA, compared with the control group, were observed in broilers after continuous 42-day long $1.5 \%$ linseed oil consumption. The fact that the response of chicken to changes in dietary fat composition is quite rapid (Waldroup and Waldroup 2005), supports opinion that using longer period is not necessary and even not recommended. However, the total correlation among hepatic IGF-1 mRNA and $\omega-6 / \omega-3$ PUFA ratio was negative. Because most of the circulating IGF-1 (about $80 \%$ ) is synthesized in liver and released into the bloodstream, there is positive correlation between hepatic IGF-I mRNA level and the plasma IGF-I profile during post-hatching development in the chicken (Burnside and Cogburn 1992). IGF-1 concentration in plasma increases with the age of the birds (Beccavin et al. 2001, Yun et al. 2005) as well as the hepatic expression of IGF-I that peaks at 28 days of age (Burnside and Cogburn 1992), and may even increase until 7 weeks of age (Giachetto et al. 2004, Yun et al. 2005). Therefore, the slight oscillations in hepatic IGF-1 mRNA level observed in the current study suggest that circulating IGF1 can be minimized or in unchangeable level by consumption of linseed meal for the aims of enriching broiler meat with $\omega-3$ PUFA. This suggestion agrees with the conclusions by Giachetto et al. (2004): additional temporal regulatory mechanisms related to nutrition are involved in modulating the expression of hepatic IGF-I mRNA and the consequent increase in plasma IGF-I levels. Additionally, Ghoshal et al. (2000) has found that in rats the mRNA level of IGF-1 in liver and IGF-1 concentration in serum are less affected by the diet containing 20\% corn oil (CO) compared with those fed 5\% CO. Similarly, in a later report (Mazucco et al. 2005) have shown that in white leghorns, 5\% linseed oil had no effect on hepatic IGF-1 mRNA or circulating IGF-1 after 5 weeks long diet. Dunn 
Vol. 18 (2009): 35-44.

et al. (2003) have shown that flax has no affect on circulating IGF-1 concentrations in cattle. This is in fact somewhat surprising, given Watkins et al. (1997) observation, that dietary lipid treatment could positively alter the IGF-1 concentration in blood and liver of the chicken at the age of 21 days. However, they used different fatty acid obtained from soybeans, menhaden and corn.

To the best of our knowledge the level of blood serum IGF-1 tends to decrease and to suppress quail leukocyte IGF-1 gene expression upon feeding with the mix of linseed and rapeseed meal as the final diet (Karus et al., 2007). In contrast, there is small but significant increase in IGF-1 gene expression in leukocytes of broilers of the age of 42 days, after three weeks feeding with linseed meal. Therefore, our results do not completely rule out the endocrine mode of IGF-1 action.

In conclusion, the results of the current study demonstrate that various supplements of linseed meal enhance the nutritional quality of broiler meat. Under our experimental conditions, the effect of absorbed PUFA acids is quantitatively related to IGF-1 gene expression level in several tissues. However, the exact mechanism through which PUFA affects IGF-1 gene expression is still not known. We suggest that paracrine and/or autocrine functions of IGF-1 are involved in the absorption of fatty acids from linseed meal. Our results show that $15 \%$ linseed cake at starting period or the $1.5 \%$ linseed oil consumption at final diet results in the enrichment of broiler meat with $\omega-3$ PUFA.

Acknowledgements. This work was supported by the pilot project P0091LATD04 and by the grant No 5734 from the Estonian Science Foundation.

\section{References}

Beccavin, C., Chevalier, B., Cogburn, L.A., Simon, J. \& Duclos, M. J. 2001. Insulin-like growth factors and body growth in chickens divergently selected for high and low growth rate. Journal of Endocrinology 168: 297-306.

Burnside, J. \& Cogburn, L.A. 1992. Developmental expression of hepatic growth hormone receptor and insulin-like growth factor-I mRNA in the chicken. Molecular and Cellolar Endocrinology 89: 91-96.

Ciceran, M. 2004. Common flax - Linum usitatissimum. Flowers. Cited 01 November 2007. Updated 03 January 2007. Available on the Internet: http://www.istrianet.org/ istria/flora/flowers/linum-usitatissimum.htm

Dunn, J.D., Johnson, B.J., Kayser, J.P., Waylan, A.T., Sissom E.K. \& Drouillard, J.S. 2003. Effects of flax supplementation and a combined trenbolone acetate and estradiol implant on circulating insulin-like growth factor-I and muscle insulin-like growth factor-I messenger RNA levels in beef cattle. Journal of Animal Science 81: 3028-3034.

Ghoshal, A., Xu, Z., Wood, G. \& Archer, M. 2000. Induction of hepatic insulin-like growth factor binding protein-1 (IGFBP-1) in rats by dietary n-6 polyunsaturated fatty acids. Proceedings of the Society for Experimental Biology and Medicine 225: 128-135.

Giachetto, P., Riedel, E., Gabriel, J., Ferro, M., Di Mauro S., Macari, M. \& Ferro, J. 2004. Hepatic mRNA expression and plasma levels of insulin-like growth factor-I (IGF-I) in broiler chickens selected for different growth rates. Genetics and Molecular Biology 27: 39-44.

Guernec, A., Chevalier, B. \& Duclos, M.J. 2004. Nutrient supply enhances both IGF-I and MSTN mRNA levels in chicken skeletal muscle. Domestic Animal Endocrinology 26: 143-154.

Heck, A., Metayer, S., Onagbesan, O. M. \& Williams, J. 2003. mRNA expression of components of the IGF system and of $\mathrm{GH}$ and insulin receptors in ovaries of broiler breeder hens fed ad libitum or restricted from 4 to 16 weeks of age. Domestic Animal Endocrinology 25: 287-294.

Hämmal J. 2004. Possibilities to enrich poultry products with $\Omega-3$ fatty acids and influence of these acids to the human health. PhD thesis, EAU, Tartu, $143 \mathrm{p}$.

Karus, A., Saprõkina, Z., Tikk, A., Järv, P., Soidla, R., Lember, A., Kuusik, S., Karus, V, Karus., Kaldmäe, H., Roasto, M. \& Rei, M. 2007. Effect of Dietary Linseed on Insulin-Like Growth Factor-1 and Tissue Fat Composition in Quails. Archiv für Geflügelkunde/European Poultry Science 71: 81-87.

Katsumata, M., Kawakami, S., Kaji, Y., Takada, R. \& Dauncey, M. J. 2002. Differential Regulation of Porcine Hepatic IGF-I mRNA Expression and Plasma IGF-I Concentration by a Low Lysine Diet. Journal of Nutrition. 132: 688-692.

Lopez-Ferrer, S., Baucells, M.D., Barroeta, A.C., Galobart, J. \& Grashorn, M.A. 2001. n-3 Enrichment of Chicken Meat. 2. Use of Precursors of Long-Chain Polyunsaturated Fatty Acids: Linseed Oil. Poultry Science 80: 753-762.

Lember, A., Tikk, H., Tikk, V., Tamm, K., Karus, A., Kuusik, S. \& Rei, M. 2006. The use of linseed oil in enriching the lipids of hen broiler, quail and rabbit meal with $\omega-3$ Fatty acids. Agraarteadus/Journal of Agricultural Sciences XVII: 45-67.

Mazzuco, H., McMurtry, J.P. \& Hester, P.Y. 2005. Effect of moulting and pre- and post-molt diets high in omega- 3 fatty acids on circulating insulin-like growth factor-1 in White Leghorns (abstract). Poultry Science 84: 110.

McMurtry, J.P., Francis, G.L. \& Upton, Z. 1997. Insulin-like growth factors in poultry. Domestic Animal Endocrinology 14: 199-229. 


\section{AGRICULTURAL AND FOOD SCIENCE}

Saprõkina, Z. et al. Dietary linseed supplement effect on broiler IGF-1 expression

Pfaffl, M. 2001. Development and validation of an externally standardised quantitative insulin-like growth factor-1 RTPCR using LightCycler SYBR Green I Technology. In: Meuer, S., Wittwer, C. \& Nakagawara, K. (eds.). Rapid cycle Real-Time PCR. Berlin: Springer, p. 281-291.

Pfaffl, M., Mircheva Georgieva, T., Penchev Georgiev, I., Ontsouka, E., Hageleit, M. \& Blum, J. 2002. Real-time RT-PCR quantification of the insulin-like growth factor (IGF)-1, IGF-1 receptor, IGF-2, IGF-2 receptor, insulin receptor, growth hormone receptor, IGF-binding proteins 1,2 and 3 in the bovine species. Domestic Animal Endocrinology 24: 91-102.

Smolkina, Z. \& Karus, A. 2004. IGF-1 and some housekeeping gene candidates for real-time RT-PCR expression studies in cattle. Agraarteadus/Journal of Agricultural Sciences XV: 38-46.
Tikk, H. \& Lember, A. 2004. Increasing the content of the $\omega$-3-fatty acids in the chicken meat. Agraarteadus/Journal of Agricultural Sciences XV: 250-258.

Waldroup, P.W. \& Waldroup, A.L. 2005. Fatty Acid Effect on Carcass: the Influence of Various Blends of Dietary Fats Added to Corn-Soybean Meal Based Diets on the Fatty Acid Composition of Broilers. International Journal of Poultry Sciences 4: 123-132.

Watkins, B., Shen, C., McMurtry, J., Xu, H., Bain, S., Allen, K. \& Seifert, M. 1997. Dietary Lipids Modulate Bone Prostaglandin E2 Production, Insulin-Like Growth Factor-I Concentration and Formation Rate in Chicks. The Journal of Nutrition 127: 1084-1091.

Yun, J.S., Seo, D.S., Kim, W.K. \& Ko, Y. 2005. Expression and relationship of the insulin-like growth factor system with posthatch growth in the Korean Native Ogol chicken. Poultry Science 84: 83-90. 